\title{
Competition in the Polish Banking Sector ${ }^{* *}$
}

\section{Introduction}

Competition among banks is a subject of interest to bank managers, financial markets, bank supervisors and academics. This interest is driven by increasing consolidation in the banking sector, changes in production technology and regulation.

The establishment of the European Monetary Union (EMU) has radically transformed institutional conditions in the European financial market and improved the integration of financial services. The most important channels of the EMU's influence on banking competition were consolidation and deregulation. Greater concentration enabled banks to profit from economies of scale. At the same time, a reduction of bank entry requirements led to greater competition in the market. However, the integration of financial services has spurred increased competition in corporate banking, which kept the retail sector segmented and country-oriented.

Competition between banks is a crucial issue for new European Union countries, including Poland. Consolidation and financial deregulation were the main channels that were observed in the EU at the time of switching to the euro; the same channels influenced competition in the Polish banking sector after the country's EU accession. This was mainly due to a consolidation process that was firmly connected to the process of privatizing Poland's banks, based mostly on foreign capital from the euro area.

To carry out a quantitative assessment of changes in the level of competition in the Polish banking sector, the Panzar and Rosse method was applied. In order to evaluate differences between competition in individual banking segments, the micro-panel data sample for Poland was divided into three groups: the banking sector as a whole (commercial banks), retail banks, and corporate banks. The micro-panel data for the Polish banking sector was obtained from the National Bank of Poland's statistics for the 1997-2007 period.

To assess the level of competition in the Polish banking sector, two variants of the Panzar and Rosse method were used. The first variant explains the

" The author works at the Economic Institute of the National Bank of Poland; malgorzata. pawlowska@nbp.pl. The article was submitted in May 2010.

** This paper was presented at the CICM Conference in London Sept. 17-18, 2009. The views expressed in this paper are the views of the author and do not necessarily reflect those of the National Bank of Poland. 
natural logarithm of interest income divided by total assets as the dependent variable, whereas the second variant is based on the natural logarithm of interest income.

The empirical results indicate that the Polish banking industry is a market with monopolistic competition. This means that the level of competition among commercial banks operating in Poland does not significantly diverge from the level observed among credit institutions in the euro area, where monopolistic competition prevails as well. Competition in the retail market is slightly higher than in the corporate market, though the level of competition in the corporate market has increased after Poland's EU entry.

\section{Theory and a review of literature}

\section{Methods of competition measurement}

Competition in the banking sector is analyzed with the use of market force and effectiveness measures. Research on competition is currently conducted as part of an industrial organization approach to banking.

The following research trends can be distinguished in the literature concerning research on competition: a trend developed on the basis of economic theories investigating the industrial organization (IO) ${ }^{1}$ and the new empirical industrial organization theory (NEIO). The traditional IO theory comprises the following theories: the structure-conduct-performance paradigm (SCP) describing the relationship between the market structure, company conduct and performance, and a theory based on the efficient structure hypothesis (ESH).

The structure-conduct-performance paradigm (SCP) based on testing the relationship between the market structure, company conduct and its performance, was defined by Bain (1951); thus concepts such as Bain's research program or Bain's paradigm are also found in the literature. According to this approach, market performance depends on market conduct, which is determined by the main components of the market structure determining its competitiveness. Under the SCP theory, the mechanism of the market structure's influence on competitive conduct and the results of management come down to a conventional approach to the relationship between the level of competition and the market structure. This approach is based on the assumption that higher concentration is accompanied by lower competition between companies.

The theory based on the efficient structure hypothesis was developed by economists connected with the Chicago School [Demsetz, 1973]. The authors of the ESH theory proposed a different approach to explaining the relationship between the market structure and firm performance, i.e. an approach based

1 In the above theory, which deals with market organization and competition, the behavior of firms is investigated under certain limitations imposed by consumers and competitors. The central issue of this theory was an expansion of the microeconomic analysis with imperfectly competitive markets and the main model discussed in this theory is the oligopoly model. 
on efficiency. The ESH theory also defines a positive influence of concentration on performance, similar to the SCP theory; however, the justification for that is different. According to the ESH theory, more efficient firms have lower operating costs and therefore achieve higher profits. In addition, the ESH theory assumes that if a firm (bank) is more efficient than other competitors, it must choose between two mutually exclusive strategies. The first strategy concerns the maximization of profit for shareholders by maintaining existing prices and the firm's size. According to the other strategy, profit maximization is based on price reduction, and thus on increasing the firm's market share. Under these assumptions, the increasing efficiency of firms leads to higher concentration.

In both the SCP and ESH models, the measures of market concentration (i.e. $\mathrm{CR}_{\mathrm{k}}$ and Herfindahl-Hirschman indices) are used for explaining reasons for non-competitive behaviors and are also treated as measures of the consequences of a different efficiency of market players [Pawłowska, 2005, p. 12]. In both the SCP and ESH models, empirical research was based on adopting a specific initial market structure and on formulating and testing hypotheses on the basis of the sign and value of individual parameters in the models. As a consequence of using such a methodology, the market structure, determining the behavior of firms, was usually used in structural models as an exogenous variable.

An incentive for developing a new analytical theory of competition (NEIO) in the early 1970s was abstracting the market structure as an endogenous variable. The authors of the new theory dealing with market organization and competition stated that the market form is created evolutionarily and depends on many market characteristics as well as the strategic behaviors of firms/banks themselves. According to NEIO, concentration is an endogenous variable and depends on the behaviors of individual market players that are exogenous from the firm's perspective.

Methods based on NEIO do not take into account the direction of changes in the level of concentration and they presume that the degree of competition does not always depend on concentration measures because other market characteristics, such as dynamic barriers to entry and exit, are more important. According to the new NEIO competition theory, when assessing the intensity of competition, two factors should be assessed jointly: the level of concentration and the possibility of entering a particular industry, determined by dynamic barriers to entry. Therefore, structural concentration measures are excluded in the measurement of the degree of competition.

In the contestable markets theory (CMT), proposed for the first time by Baumol (1982) and regarded as a non-structural model, authors explicitly take into consideration the strategic behaviors of firms/banks and the presence of potential competition. According to the CMT, the absence of entry and exit barriers forces an already existing firm to take into account the possibility of new firms entering the market - potential competitors [Łyszkiewicz, 2002, p. 266]. 
Methods based on the new empirical industrial organization theory (NEIO) include the Iwata method (1974), the Bresnahan [1989] and Lau method [1982], and the Panzar-Rosse [1987] method.

It should be noted that both the Iwata method and the Bresnahan and Lau model were scarcely applied in empirical studies. By contrast, the Panzar and Rosse (P-R) model received widespread acceptance among the academic community. In addition, empirical research based on the NEIO theory is conducted with the use of the Lerner index (1934) on the basis of the Monti-Klein oligopolistic model [Freixas and Rochet, 2008, pp. 72-73].

Recently research reports on the measurement of competition in the banking sector have applied - apart from the widely used Panzar-Rosse measure (1987) and the Lerner index - the so-called Boone indicator, proposed by Boone [2000], which is based on the ESH theory [i.e. Leuvensteijn et al., 2007].

\section{Results of the measurement of competition in European banking sectors - overview of literature}

The importance of competition in the financial sector is the subject of research by bank analysts because the level of competition in the financial sector may influence the effectiveness of financing and the availability of financial services to companies and households and may have an impact on the quality of products. Empirical cross-country investigations in this research area are primarily related to the influence of competition on the stability of the financial sector, access to external financing and economic development. In addition, the relationship between market concentration and the level of competition has been analyzed.

Gelos and Roldos [2002], using the P-R methodology and BankScope data, found that banking markets in Europe (including the Polish market) and Latin American countries did not become less competitive in the 1994-1999 period, but concentration was on the rise. These findings were confirmed by Yildrim and Philippatoas [2007] for Poland and other Central and Eastern European banking markets. Hempell [2002] reached a similar conclusion related to the German banking industry for the 1993-1998 period, Coccorese [2004] said the same of the Italian banking sector in 1997-1999. Claessens and Laeven [2004], using the P-R methodology and BankScope data on cross-country research (covering Poland), found evidence that more concentrated banking systems are more competitive.

Bikker [2004] reported that the Herfindahl-Hirschman (HHI) indices and the $k$ bank concentration ratios $\left(\mathrm{CR}_{\mathrm{k}}\right)$ tend to exaggerate the level of competition in small countries and are increasingly unreliable when the number of banks is limited. However, in recent papers, Bikker et al. [2006] and [2007a], [2007b] demonstrated that the level of competition in the existing P-R literature was systematically overestimated. All 28 studies considered, including 
the abovementioned studies, suffered from such misspecification. The main reason for this was that most studies used a scaled version of bank income as the dependent variable in the P-R model and worked with revenues divided by total assets. With the correctly specified P-R model, Bikker et al. proved that a monopoly or a perfect cartel cannot be rejected in $28 \%$ of the analyzed countries (against 0\% in the misspecified model). The analysis made it clear that further consolidation would reduce competition among banks, which would impair the welfare of consumers and companies.

Finally, Bikker and Spierdijk [2008], who were the first to analyze changes in cross-country competition in 101 countries in the last 15 years, using a proper dependent variable in the P-R model, found significant changes in the level of competition in the analyzed countries. In addition, they reported a decrease in competition in the Western European banking sector (in particular, in the euro area) and an increase in competition in the banking sectors of Eastern Europe. They also found that the level of competition between the banking sectors of the "old" and "new" EU countries leveled off. The decrease in banking sector competition in Western European economies was largely due to the establishment of large banks with considerable market strength. Another factor was a change in banks' role as the key financial intermediaries, owing to the growing significance of the capital market in lending to enterprises and an increase in banks' non-interest income. Koutsomanoli-Fillipaki and Staikouras [2006] showed that commercial banks in the new EU countries (EU10) operate under stronger competition than their counterparts in old EU countries (EU15). Stronger competition in the banking sectors of the new EU countries, including Poland, may stem from lower market entry barriers and the presence of foreign capital that displayed an upward trend in the new EU countries (EU10) in the analyzed period.

One of the few empirical studies using cross-country statistics that relate specifically to the impact of joining the EMU on increased competition in the financial sector was carried out by Utrero-Gonzalez and Callado-Muñoz (2007). Using a comparative analysis of changes in the level of competition in the banking sectors of euro- and non-euro-area countries, and the P-R methodology, the authors demonstrated a positive impact of the single European currency on increased competition in the euro-area banking sector. Furthermore, Boucinha and Ribeiro [2009] confirmed an increase in competition in the Portuguese banking system as a result of its participation in the euro area, and Luis Gutiérrez de Rozas [2007] came up with a similar conclusion for Spanish banks. Increased competition in the credit market in euro-area countries was also reported by Leuvensteijn et al. [2007]. Leuvensteijn et al. [2007] were the first to apply a new measure of competition, the Boone indicator, to the credit market in euro-area countries. However, the paper pointed to differences in the level of competition among individual euro-area countries. 


\section{The Panzar and Rosse Model}

\section{Theoretical framework}

Panzar and Rosse [1977, 1987] developed a test for competitive market conditions based on a reduced-form revenue equation of the firms. The test was based on empirical observation of the impact of variations in factor input prices on firm-level revenues.

The method was derived from a general banking market model ${ }^{2}$, which determines the equilibrium output and the equilibrium number of banks, by maximizing profits at both the bank level and the industry level. This implies, first, that bank $i$ maximizes its profits, where marginal revenue equals marginal cost [Bikker 2004, pp. 85-86)]:

$$
\begin{aligned}
& R_{i}^{\prime}\left(y_{i}, n, z_{i}\right)=C_{i}^{\prime}\left(y_{i}, w_{i}, t_{i}\right) \\
& R_{i}^{*}\left(y^{*}, n^{*}, z\right)=C_{i}^{*}\left(y^{*}, w, t\right)
\end{aligned}
$$

where: $R_{i}$ - revenue function of bank $i, C_{i}$ - cost of bank $i, y_{i}$ - output of bank $i, n$ - number of banks, $w_{i}$ - factor of input prices of bank $i, m$ - number of factor input prices, $z_{i}$ - vector of exogenous variables that shift the revenue function, $z_{i}$-vector of exogenous variables that shift the cost function.

Market power is measured by the extent to which a change in factor input prices $\left(\partial w_{k i}\right)$ is reflected in equilibrium revenues $\left(\partial R_{i}^{*}\right)$ earned by bank $i$. In order to identify the nature of the market structure (oligopoly, monopoly competition or perfect competition), the Panzar and Rosse model (P-R) provided a measure called the $H$-statistic. Panzar and Rosse showed that the sum of the elasticity of the total interest revenues, with respect to changes in banks' input prices $\left(w_{i}\right)$, makes it possible to draw conclusions about the banks' competitive conduct - see equation (3). The above methodology entails various assumptions, which are discussed below; for more information see: [Gelos and Roldos, 2002, p. 13], [Bikker, 2004, pp. 85-86].

$$
H=\sum_{k=1}^{m} \frac{\partial R_{i}^{*}}{\partial w_{k i}} \cdot \frac{w_{k i}}{R_{i}^{*}}
$$

where: $R_{t}^{*}$ - revenue function in equilibrium of bank $i, w_{k i}$ - factor of input prices of bank $i, m$ - number of factor input prices.

The estimated value of the $H$-statistic ranges between $-\infty$ and 1. Moreover, Panzar and Rosse [1987] showed that in a market equilibrium, perfect competition is indicated by a $H$-statistic equal to unity. Under perfect com-

2 Cournot oligopoly model with profit maximinization by collusive Cournot oligopolies. 
petition, an increase in input prices and thus in average costs should lead to a proportional price increase and (at the firm level) to a proportional rise in revenues. Under monopolistic conditions, an increase in input prices will increase marginal costs, reduce equilibrium output and consequently reduce total revenues, and the $H$-statistic is negative or equal to zero. If the market structure is characterized by monopolistic competition, the $H$-statistic will lie between zero and unity [Bikker (2004, pp. 86-87)] (see Table 1).

The first market model that Panzar and Rosse investigated described a monopoly (Panzar and Rosse [1987], pp. 445-446)3. Panzar and Rosse also proved that the $H$-statistic is equal to $e-1$ and yields an estimate of the Lerner index of monopoly power $L=(e-1) / e=H /(H-1)$, where $e$ is price elasticity.

Table 1

Interpretation of the $\boldsymbol{H}$-statistic

\begin{tabular}{|c|l|}
\hline & \multicolumn{1}{|c|}{ Competitive Environment } \\
\hline$H \leq 0$ & Monopoly or perfectly collusive oligopoly \\
\hline $0<H<1$ & Monopolistic competition \\
\hline$H=1$ & $\begin{array}{l}\text { Perfect competition, natural monopoly in a perfectly contestable market, or sales } \\
\text { maximizing firm subject to a break-even constraint }\end{array}$ \\
\hline & \multicolumn{1}{c|}{ Equilibrium test } \\
\hline $0<H$ & Disequilibrium \\
\hline$H=0$ & Equilibrium \\
\hline
\end{tabular}

Source: [Hempell, 2002, p. 8], [Bikker, 2004, p. 87]

The nature of the estimation of the $H$-statistic means that one is especially interested in understanding how interest revenues react to variations in the cost figures. Also, the methodology requires an assumption that banks use three inputs/funds - financial capital, labor, and physical capital. This is consistent with the intermediation approach under which a bank is viewed as a firm collecting deposits and other funds in order to transform them into loans and other assets [Sealey and Lindley, 1977]. Another assumption is that higher input prices are not associated with higher quality services that may generate higher revenues, since such a correlation may bias the computed $H$-statistic. Finally, the test must be undertaken on observations that are in a long-run equilibrium ${ }^{4}$. This means that the price should equal the marginal cost and that free entry and exit conditions determine zero economic profit. $H<0$ would show a nonequilibrium, whereas $H=0$ would point to an equilibrium [Shaffer, 1982)].

The Panzar and Rosse approach (P-R) has some limitations. The general limitations are the assumptions underlying its use as a measure of competition

3 For more see Annex B.

4 An empirical test for equilibrium is justified on the grounds that competitive capital markets will equalize the risk-adjusted rate of return across banks to such an extent that equilibrium rates of return should not be statistically correlated with input prices. 
in the banking industry as well as the resulting biases. Generally, the Panzar and Rosse approach was developed on the basis of static (oligopoly) models whereas for dynamic models there are no predictions for the value of the $H$-statistic [Corts, 1999]. Furthermore, Bikker, Spierdijk and Finnie [2007] provided empirical evidence that the level of competition in the banking industry in the existing empirical P-R literature is systematically overestimated. The reason for the misspecifications is that most studies use different definitions of the appropriate variable to represent banks' revenue (different definitions of the dependent variable in the P-R model). These issues will be discussed in detail in the next subsection. However, despite these limitations, the P-R model has been extensively applied to the banking sector in a number of countries.

\section{Misspecification in the Panzar and Rosse (P-R) model}

It should be stressed that Bikker et al. [2007a] provided empirical evidence to show that the scaled P-R model is misspecified. The reason for this misspecification is that most studies use scaled versions of bank income as the dependent variable in the P-R model and work with revenues divided by total assets. However, scaling changes the nature of the model fundamentally, since it transforms the revenue equation into a price equation.

Following Bikker and Haff [2002], the empirical translation of the P-R approach assumes a log-linear marginal cost (MC) function of the form ${ }^{5}$ :

$$
\ln M C=\alpha_{0}+\alpha_{1} \ln y+\sum_{i=1}^{m} \beta_{i} \ln w_{i}+\sum_{j=1}^{p} \gamma_{j} \ln o t h_{j}^{C}
$$

Where $y$ is the output of bank, $w_{i}$ is the factor of input prices and $o t h_{j}^{c}$ represent other variables exogenous to the cost function.

Similarly, the marginal revenue (MR) function is assumed to have a loglinear form, thus:

$$
\ln M R=\delta_{0}+\delta_{1} \ln y+\sum_{k=1}^{q} \varepsilon_{k} \ln o t h_{k}^{R}
$$

Where $y$ is the output of bank, oth ${ }_{k}^{R}$ represents other variables related to the bank-specific demand function.

For profit maximization a bank's marginal cost equals marginal revenues in an equilibrium. This results in the equilibrium value:

$$
\ln y^{*}=\left(\alpha_{0}-\delta_{0}+\sum_{i=1}^{m} \beta_{i} \ln w_{i}+\sum_{j=1}^{p} \gamma_{j} \ln o t h C+\sum_{k=1}^{q} \varepsilon_{k} \ln o t h_{k}^{R}\right) / \delta_{1}-\delta_{0}
$$

5 Based on the Cobb-Douglas function. 
The reduced-form revenue equation is obtained as the product of equilibrium output and the common price level. The common price level is determined by the inverse demand equation, which in logarithmic form is expressed as:

$$
\ln p^{*}=\zeta+\ln \left(\sum_{i} y_{i}^{*}\right)
$$

Building on this framework, Bikker and Haaf (2002) arrive at the following empirical reduced-form equation of the P-R model:

$$
\ln I I=\alpha+a_{1} \ln w_{f}+a_{2} \ln w_{p}+a_{3} \ln w_{c}+\sum_{j} \beta_{j} o t h_{j}+\eta(O I / I I)+\varepsilon
$$

where $\ln I I$ denotes the natural logarithm of interest income, $w_{f}$ - the price of funds, $w_{l}$ - the price of labor, $w_{c}$ - the price of capital, oth - bank-specific exogenous factors, and $O I / I I$ - the ratio of other income to interest income, $\alpha$ - is a constant term, $\varepsilon$ - error.

The $H$-statistic is calculated as the sum of the elasticity of a bank's total revenue with respect to the bank's input prices $\left(w_{l}, w_{c}, w_{f}\right)$, i.e. $H=a_{1}+a_{2}+a_{3}$ based on equation (8).

The dependent variable in equation (8) may be defined as $\ln I I$ or in some other way (see below); also the choice of explanatory variables may vary.

Whereas many articles use as the dependent variable the natural logarithm of interest income divided by total assets for bank $i$ in time $t\left(y_{i t}=\ln (I I / T A)_{i t}\right)$, others take the natural logarithm of interest income for bank $i$ in time $t\left(y_{i t}=\ln \left(I I_{i t}\right)\right)$. However, the natural logarithm of interest income divided by total assets is "the price," as the natural logarithm of interest income is "the revenue" - the correct dependent variable in the P-R model.

The choice of the dependent variable explains why previous studies found that the $H$-statistic increases with bank size [Bikker et al., 2006, pp. 17-18]. To see this, let us consider equation (8) like a simple panel regression model:

$$
y_{i t}=\alpha_{i}+\mathbf{x}_{\mathbf{i t}}^{T} \beta+\varepsilon_{i t}, i=1, \ldots, N \quad t=1, \ldots, T .
$$

where:

$\mathbf{x}_{\mathbf{i t}}$ is the $i t$-th observation on $K$ explanatory variables appearing in equation (8) (all input prices and other bank-specific exogenous factors of bank $i$ in time $t, \beta-$ is a $K \times 1$ vector of coefficients).

Let us denote by $\hat{\beta}_{p}$ the OLS estimator of $\beta$ with $y_{i t}=\ln (I I / T A)_{i t}$ as the dependent variable and by $\hat{\beta}_{r}^{6}$ the OLS estimator with $y_{i t}=\ln \left(I I_{i t}\right)$. It is easy to show that $\hat{\beta}_{p}=\hat{\beta}_{r}+$ linear function of $\ln \left(T A_{i t}\right)$. Obviously, $H$-statistics cal-

6 Where the subscripts ' $p$ ' and ' $r$ ' refer to the dependent variable in the P-R model, being either 'the price' or 'the revenue'. 
culated from $\hat{\beta}_{p}$ and $\hat{\beta}_{r}$ are clearly different and the "bias" of $H_{p}$ with respect to $H_{r}$ is the function of total assets ${ }^{7}$. Bikker et. al. [2006] showed that the "bias" is virtually always nonnegative and must be an increasing function of the total assets.

Another important issue is the specification of explanatory variables in the P-R model. All inputs are used to generate total income $(T I)$, so that: $\ln (T I)=\ln (I I+O I) \approx \ln (I I)+O I / I I$, where $I I$ is interest income and $O I / I I$ is the ratio of other income (commission and fee income) to interest income. Therefore, in the specification of the model, we should use as the explanatory variable the ratio of other income to interest income variable $(O I / I I)$, like in equation (8).

\section{Structural and technological changes in the Polish banking sector in 1997-2007}

\section{Changes in the structure}

The deregulation of 1989 radically restructured the banking systems in both Poland $^{8}$ and other new EU countries. It started the process of privatization and consolidation in the banking industry, which was previously dominated by a few government-controlled banks.

Currently, the Polish banking sector is made up of commercial and cooperative banks. ${ }^{9}$ Commercial banks dominate; at the end of 2007, they accounted for $94 \%$ of total banking sector assets (see Table 1 in Statistical Annex 1).

Due to intensive consolidation in 1997-2002, the number of Polish commercial banks significantly decreased, but at the same time the number of branches increased (see Fig. 1). Consolidation was associated with the privatization of nearly all state-owned banks, as a result of which the share of banks controlled by foreign investors climbed to $70 \%$. The role of foreign-controlled banks stabilized between 2000 and 2007 (Table 1 in Statistical Annex 1). At the end of 2007, ten commercial banks were Polish-owned, of which four were controlled by the State Treasury. Foreign investors held a majority interest in 40 domestic commercial banks. The largest market share was held by banks controlled by Italian, German and Dutch owners [Financial Supervision Authority, 2008, p. 21].

The number of credit institutions in euro-area countries has also decreased (see Fig. 2). The structural changes in Poland's banking sector were similar to those in other new EU countries.

7 Note that the $H$-statistic is the sum of the OLS coefficient of the input prices; i.e. $H=\beta_{1}+\beta_{2}+\beta_{3}$.

8 In 1989, a two-tier structure was established in Poland's banking sector, with nine regional commercial banks.

9 Cooperative banks are not of interest in this research. 
Figure 1. Number of Polish commercial banks and branches in 1997-2007

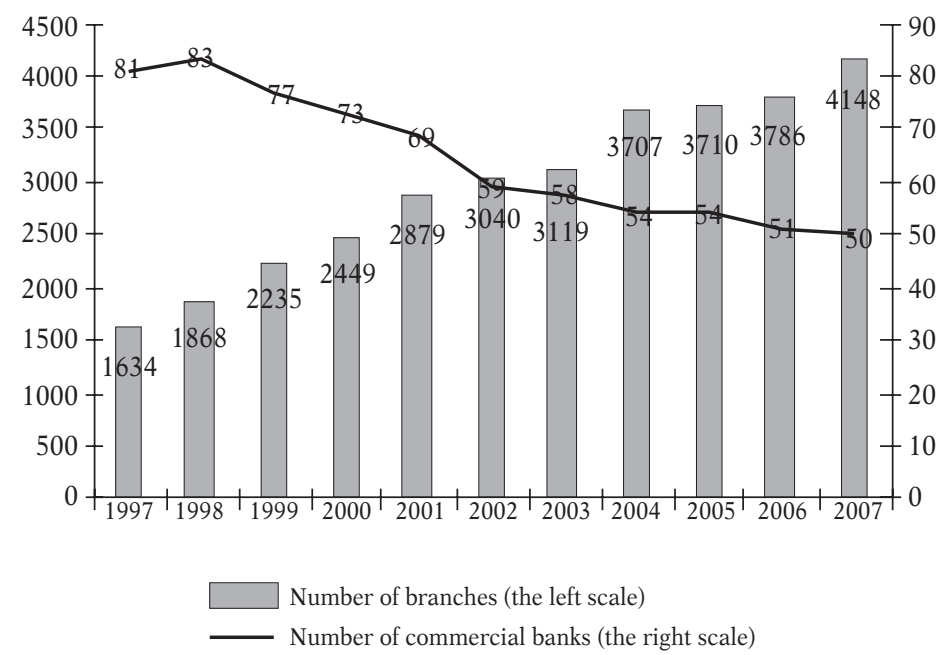

Source: NBP

Figure 2. Number of credit institutions (CIs) in 12 Monetary Union (MU12) countries in 1997-2007

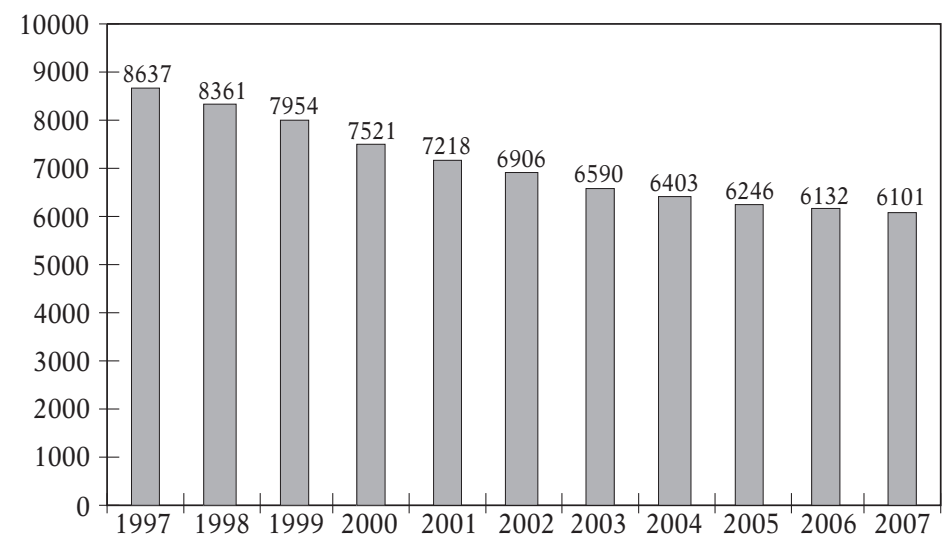

Source: ECB

In 1997-2007, foreign parent banks started to integrate the operations of Polish subsidiaries with their strategic policies and designate specific specialization. The integration process led to the development of a few strategic banking groups (differentiated by features such as target customers, services offered/type of loans, and sources of financing). There were two main groups of banks: retail and corporate banks. Currently, retail banking is the largest segment of the Polish banking industry and the fastest growing part of the banking sector 
in Poland ${ }^{10}$. Retail banks focus on serving individual customers, entrepreneurs, and small enterprises. However, after Poland's EU accession in May 2004, corporate banking started to develop fast, mainly due to a rapidly developing market for corporate debt securities.

\section{Changes in profitability}

During the analyzed period, the financial performance of Polish banks improved continually (see Table 2 in Statistical Annex 1). The profitability of assets and equity increased, while the value of net interest margins dropped. Some signs of an economic slowdown in 2000 , followed by a reduced creditworthiness of businesses, led to a temporary reduction in bank profits. However, starting from 2004, the performance of commercial banks improved significantly, in a trend that was associated with Poland's EU accession. A better business environment resulted in a decrease in non-performing loans (NPL) ${ }^{11}$ and an improvement in other profitability ratios.

It must be emphasized that the assessment of the financial condition of the banking sector may be to an extent distorted by the International Financial Reporting Standards (IFRS) in force since the beginning of 2005 and by the implementation of the New Basel Capital Accord (Basel II) ${ }^{12}$.

The net interest margin (NIM) ${ }^{13}$ in 2007 was about $3.1 \%$ lower than in 1997, in part due to a decrease in net interest income and an increase in competition. Another factor contributing to the decrease in the net interest margin in the analyzed period was a fall in nominal interest rates, resulting from a decreased inflation rate.

\section{M\&As and concentration in the Polish banking industry}

European mergers (see Table 4 in Statistical Annex A) have led to massive consolidation processes in many transition countries and also influenced Poland. In the first part of the 1990s, the main reason for mergers and acquisitions (M\&As) in the Polish banking sector was the acquisition of weaker or troubled banks cheaply and their subsequent incorporation into stronger banks ${ }^{14}$. M\&As taking place in 1997-2001 were a natural consequence of privatization and foreign investment in the Polish banking sector and were influenced by

10 Retail banks accounted for about $80 \%$ of total commercial bank assets.

11 Until the end of 2003, the asset classification in the Polish regulatory system was more restrictive than in many other countries. This was one of the reasons behind a decrease in the ratio of irregular loans to total loans.

12 In Poland, the New Capital Accord was introduced under law in 2007, while the possibility of using the IRB approach in banks was introduced on Jan. 1, 2008 (and is consequently not covered by this research).

13 The ratio of net interest margin to total assets is calculated as the quotient of net interest income and average assets in a given year: relation of net interest income and assets.

14 For example, a merger between Powszechny Bank Kredytowy SA and Pierwszy Komercyjny Bank SA. 
international consolidation. In 1997-2001, M\&As conducted by large banks contributed to an increased level of concentration measures.

A study of M\&A processes in 1997-2001 showed the following types of mergers in the Polish banking sector: a merger between a Polish bank acquired by a foreign investor and a foreign bank-operated subsidiary in Poland ${ }^{15}$; a merger between two Polish banks having a common foreign shareholder16; a merger between banks operating within the same group ${ }^{17}$; a merger between banks in Poland initiated by a merger of shareholding banks outside Poland ${ }^{18}$.

In 2002-2007, the consolidation process slowed down. Furthermore, slower development of large banks and a more rapid development of small and mediumsized banks caused a drop in the $\mathrm{CR}_{5}$ concentration index between 2002-2007 (see Fig. 3). However, in 2002-2007, the level of concentration measures in MU12 countries increased (see Fig. 4).

Figure 3. $\mathrm{CR}_{5}$ for Polish commercial bank assets in 1997-2007 in (\%)

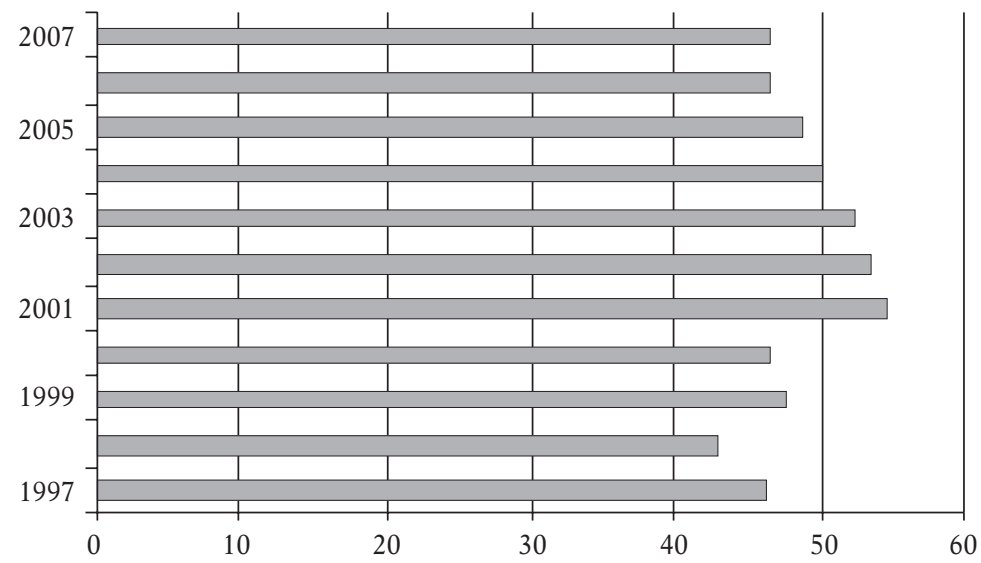

Source: own analysis.

15 For example, Citibank (Poland) SA merged with Bank Handlowy w Warszawie SA, and both banks are now controlled by Citibank Overseas Investment Corp.). Another example was the acquisition of ING Bank N.V. Oddział w Warszawie by ING Bank Śląski SA owned by ING Bank NV.

16 For example, a merger of Bank Zachodni SA and Wielkopolski Bank Kredytowy SA, both controlled by Allied Irish Bank European Investments Ltd.

17 For example, the acquisition of the Pekao SA banking group, which was established on the basis of four state-owned banks that were part of this group.

18 For example, a merger of Powszechny Bank Kredytowy SA with Bank Przemysłowo-Handlowy $\mathrm{SA}$ as a result of a merger between their shareholders - Bank Austria Creditanstalt and HypoVereinsbank. 
Figure 4. HHI for assets of Polish commercial banks and MU12 credit institutions (CIs)

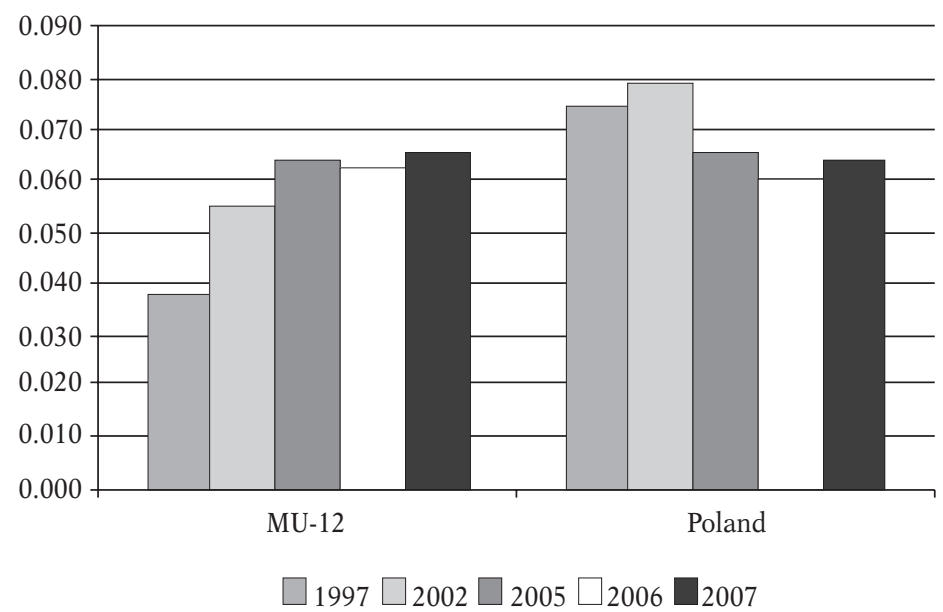

Source: ECB (2007a) and own analysis

\section{Contestability}

Banking contestability is a major condition for the level of competition. On May 1, 2004, ten new member countries including Poland joined the European Union. One of the results of the accession was the harmonization of Poland's financial law with EU regulations. The most important change in the business environment for the Polish banking sector, after the country's EU entry, was that the "single banking passport" principle came into force. This means that a credit institution authorized in one EU member state is authorized to do business in another (to the extent of the authorization it receives in its home country). Banks that are licensed in any EU country have the right to open new branches and conduct operations in any other member state without undergoing new licensing procedures. Banking services may then be provided either via branches or on a cross-border basis. As a result, Polish banks are subject to stiffer competitive pressure: domestic banks have higher levels of general expenses than banks in other EU countries. New branches of foreign banks may enjoy a competitive edge over domestic banks due to lower costs (resulting from the use of their parent bank's IT systems, for example).

Technical solutions have also become an important internal factor that enables banks to streamline their management systems, improve work quality and create new distribution channels. Furthermore, the internet has made established banking sectors more vulnerable to new entrants, which in consequence enhanced the level of competition.

Internet banking has been one of the fastest growing commercial applications of the internet in the Polish banking industry in the last 10 years (see Table 3 in Statistical Annex A). 


\section{Analysis of the level of competition in the Polish banking sector - empirical results using Panzar and Rosse's $H$-statistic}

In this chapter, the level of competition among Poland's commercial banks was evaluated. In order to estimate the $H$-statistic for the Polish banking sector, the following reduced-form revenue equation was estimated (for details see also [Bikker and Bos, 2008], [Claessens and Laeven, 2004], [Yildrim and Philippatoas, 2007]):

$$
\begin{gathered}
I R_{i t}=\alpha+a_{1} \cdot \ln w_{l i t}+a_{2} \cdot \ln w_{p i t}+a_{3} \cdot \ln w_{c i t}+\eta \cdot(O I / I I)_{i t}+ \\
+\sum_{j=1}^{N} b_{j} \cdot \text { oth }_{i t}+\sum_{l=1}^{L} \alpha_{l} D_{l}+\varepsilon_{i t}
\end{gathered}
$$

dependent variable:

$I R_{i t}$ - the natural logarithm of interest income $\ln (I I)_{i t}$ or the natural logarithm of interest income divided by total assets $\ln (I I / T A)_{i t}$ of bank $i$ in time $t$. the price of input is defined as follows:

$w_{\text {lit }}$ - the price of labor is the ratio of personnel expenses to total assets of bank $i$ in time $t$,

$w_{\text {pit }}$ - the price of funds is the ratio of interest expenses to total deposits of bank $i$ in time $t$,

$w_{c i t}$ - the price of capital is the ratio of other operating and administrative expenses to fixed assets of bank $i$ in time $t$.

other bank specific variables:

$O I / I I_{i t}$ - other income/interest income of bank $i$ in time $t^{19}$,

$\sum_{j=1}^{N}$ oth $_{i t}$ - the share of loans which are classified as: substandard, doubtful and loss, in total assets, the ratio of loans to total assets, the ratio of deposits to total assets, the ratio of fixed assets to total assets, of bank $i$ in time $t$,

$D_{l}$ - year dummy variables to control for yearly macro effects,

$\alpha-$ is a constant term,

$\varepsilon_{i t}-$ error.

The sum of the factor prices function (denoted with coefficients $a_{1}, a_{2}$ and $a_{3}$ ) of the reduced-form revenue equation - see equation (10) - constitutes the value of the $H$-statistic for the Polish banking industry.

To assess the impact of misspecification, two variants of equation (10) were estimated. The first variant explains the natural logarithm of interest income divided by total assets $\ln (I I / T A)$ as the dependent variable ${ }^{20}$, whereas the second model was based on the natural logarithm of interest income $\ln (I I)$. The panel

19 With the aim to capture the increasing role of non-interest revenue in banks' income.

20 Adding scaling factors (e.g. the natural logarithm of total assets) on the right-hand side of equation (10) also results in a type of misspecification and the revenue equation is indistinguishable from a price equation. 
data for this analysis comprises all Polish commercial banks for each year (see Figure 1) covered by the National Bank of Poland's balance sheet and income statement. These statistics consist of annual data from all banks reporting to the National Bank of Poland and cover the period from 1997 to 2007.

The sample of commercial banks was divided into two groups, depending on the type of customer: retail banks vs. corporate banks. Therefore, the measurement of the degree of competition was carried out for all the commercial banks and separately for retail and corporate banks. To analyze changes in the degree of competition in the Polish banking sector, the value of the $H$-statistic was calculated for the whole analyzed period (1997-2007) and for three subperiods: 1997-1998 $\left(H_{1}\right)^{21}, 1999-2003\left(H_{2}\right)$, and 2004-2007 $\left(H_{3}\right)$. The Hausman test was used to select the estimator for panel regression techniques (random effects or fixed effects) [Baltagi, 2001, p. 65] $]^{22}$.

Table 2 shows the value of the $H$-statistic, which determines the degree of competition for individual banking groups for two dependent variables $(\ln (I I / T A), \ln (I I))$ for the whole period $(1997-2007)$ and for the three sub-periods: 1997-1998, 1999-2003, 2004-200723.

Table 2

Value of $\boldsymbol{H}$-statistic for commercial banks operating in Poland

\begin{tabular}{|c|c|c|c|c|c|c|c|}
\hline \multirow{2}{*}{} & & \multicolumn{2}{|c|}{ Commercial banks } & \multicolumn{2}{c|}{ Retail banks } & \multicolumn{2}{c|}{ Corporate banks } \\
\cline { 3 - 8 } & & $\ln (I I / T A)$ & $\ln (I I)$ & $\ln (I I / T A)$ & $\ln (I I)$ & $\ln (I I / T A)$ & $\ln (I I)$ \\
\hline $\mathbf{1 9 9 7 - 2 0 0 7}$ & $\boldsymbol{H}$ & $\mathbf{0 . 6 2}{ }^{1}$ & $\mathbf{0 . 4 7 ^ { 1 }}$ & $\mathbf{0 . 6 7}{ }^{1}$ & $\mathbf{0 . 5 1}^{1}$ & $\mathbf{0 . 4 6}^{1}$ & $\mathbf{0 . 3 6}^{1}$ \\
\hline $1997-1998$ & $H_{1}$ & $0.51^{1}$ & $0.44^{1}$ & $0.64^{1}$ & $0.34^{1}$ & $0.31^{1}$ & $0.23^{1}$ \\
\hline $1999-2003$ & $H_{2}$ & $0.64^{1}$ & $0.56^{1}$ & $0.68^{1}$ & $0.58^{1}$ & $0.63^{1}$ & $0.44^{1}$ \\
\hline $2004-2007$ & $H_{3}$ & $0.60^{1}$ & $0.54^{1}$ & $0.53^{1}$ & $0.42^{1}$ & $0.52^{1}$ & $0.38^{1}$ \\
\hline
\end{tabular}

1 Null hypothesis $H=0$ and $H=1$ has been rejected at $1 \%$ significance level.

Source: own calculations. Note: to test the value of $H$ the Wald tests were used: for monopoly: $H_{0}: H \leq 0$ versus $H_{1}: H>0$, and for perfect competition: $H_{0}: H=1$ versus $H_{1}: H \neq 1$.

Of note is that, based on the value of the $H$-statistic for 1997-2007, which is given in Table 2, the degree of competition in individual market segments confirms the existence of monopolistic competition and that competition is stronger in the retail banking segment. In the whole banking sector, banks also operate under monopolistic competition. In 2004-2007, the degree of competition in the commercial bank sector as a whole was higher than in 1997-1998. In the analyzed period, the retail banking market displayed stronger competition than the corporate banking market, but after Poland's EU entry the level

21 The euro has been a feature of the financial landscape since Jan. 1, 1999, when the third stage of the EMU began.

22 Package STATA 9.2 was used for the estimation of indices of the panel analysis on an unbalanced panel of data.

23 For details information see: Statistical Annex B, Table B.1. 
of competition in the corporate and retail markets leveled off. It should be noted that the value of the $H$-statistic was larger when the dependent variable was scaled by asset.

The increase in competition in the banking sector as a whole was caused by Poland's accession to the EU: financial deregulation (the single passport principle has facilitated the entry of new banks into Poland) and the M\&A process (see: [Pawłowska, 2005]) which was strictly connected to the process of privatization based mostly on foreign capital from the euro area. Therefore, the same channels - consolidation and financial deregulation - that were observed in EU countries at the time of switching to the euro, influenced competition in the Polish banking sector at the time of EU accession.

The estimation results of the $H$-statistic for the three sub-periods have shown a slight increase in this measure. This means that the process of consolidation in the Polish banking system, which has resulted in increased concentration measures (see: Figures 3 and 4), was not translated into a lower degree of competition in 1997-2007. The increased contestability of Poland's banking sector in the wake of EU accession may have prevented a decline in competitive pressures.

Growing competition across the Polish banking sector is also reflected in a falling net interest margin. In the Polish banking system, similar to other EU countries, the net interest margin displays a downward trend, though it remains twice as high as the EU25 average. In 2004, the average net interest margin for Germany was $0.89 \%$; for Spain the figure was $0.95 \%$ and for Italy $2.48 \%$ [cf. Banque de France Bulletin, 2005].

The results of previous panel analyses for the Polish banking sector, provided by Gelos and Roldos [2002], Claessens and Laeven [2004], Bikker and Spierdijk [2008], Yildrim and Philippatoas [2007], and based on BankScope, are given in Table 3.

Table 3

Value of $\boldsymbol{H}$-statistic for the Polish banking sector

\begin{tabular}{|l|c|c|c|c|}
\hline & Year & $H$ value & Dependent variable & Number of banks \\
\hline Claessens and Laeven [2004] & $1994-2001$ & 0.77 & $\ln (I I / T A)$ & 40 \\
\hline Gelos and Roldos [2002] & 1994 & 0.54 & $\ln (I I / T A)$ & 55 \\
\hline Gelos and Roldos [2002] & 1999 & 0.53 & $\ln (I I / T A)$ & 55 \\
\hline $\begin{array}{l}\text { Yildrim and Philippatoas } \\
\text { [2007] }\end{array}$ & $1993-2000$ & 0.50 & $\ln (I I / T A)$ & 53 \\
\hline Bikker and Spierdijk [2008] & 1992 & 0.45 & $\ln (I I)$ & 50 \\
\hline Bikker and Spierdijk [2008] & 2004 & 0.03 & $\ln (I I)$ & 50 \\
\hline
\end{tabular}

Source: [Gelos, Roldos, 2002, p. 47], [Claessens, Laeven, 2004, p. 573], [Yildrim, Philippatoas, 2007, p. 203], [Bikker, Spierdijk, 2008, p. 26].

The transformation that has been taking place in European banking in recent years is driven by a number of diverse factors. These include globaliza- 
tion, liberalization, deregulation, progress in the IT sector, changes in demand for banking services, progress in European integration, implementation of the Financial Sector Assessment (FSAP) program, the introduction of the New Basel Capital Accord (Basel II), and the introduction of the single European currency. It is, therefore, difficult to explicitly state which factor has had the strongest impact on competition among financial institutions. In addition, it should be noted that the results related to changes in competition in euro-area countries are ambiguous. On the one hand, an increase in competition was found after the introduction of the euro [cf. Utrero-González and Callado-Muñoz, 2007]; on the other hand, the results obtained by Bikker and Spierdijk [2008] pointed to a decrease in competition in euro-area countries.

Furthermore, recent analyses show that the rise in competition in the financial markets of euro-area countries is mainly characteristic for a credit market exposed to strong competition from the fast developing market for corporate debt securities [Leuvensteijn et al., 2007], [ECB, 2007b]. It has also been ascertained that the increase in competition among euro-area countries has primarily taken place in corporate banking, while retail banking has continued to focus on national markets and has depended on cultural, economic and fiscal conditions in individual countries [ECB, 2007c].

\section{Robustness check}

\section{Sample}

The panel data set, which has been obtained from National Bank of Poland statistics, was unbalanced and covered all Polish commercial banks for each year of analysis. All regressions were checked for autocorrelation, heteroscedasticity, structural breaks, and stationarity.

\section{Market structure tests}

The relation between the $H$-statistic and the market structure provides a direct way to test the degree of competition in the banking sector. For this part of analysis, the usual statistical framework was applied: test for monopoly: $H: H_{0}: H \leq 0$ against $H_{1}: H>0$, and test for perfect competition: $H_{0}: H=1$ against $H_{1}: H \neq 1$. The abovementioned tests were applied for all the estimated $H$-statistics for each group in the Polish banking sector. The null hypothesis of monopoly and perfect competition was rejected at a $1 \%$ significance level.

\section{Equilibrium tests}

It should be noted that one of the key assumptions underlying the P-R model is that the analyzed banks are in a state of long-run competitive equilibrium. To test equilibrium, the Panzar and Rosse $H$-statistic was calculated in this paper, using the return on assets (ROA) ratio as the dependent variable in place of the interest revenue function in the regression equation (12) for the 1997-2007 
period. $H<0$ would show a non-equilibrium, whereas $H=0$ would point to an equilibrium. Also, the usual statistical framework to test the value of $H$ was applied. Testing for $H_{0}: H=0$ (equilibrium) against $H_{1}: H<0$ (disequilibrium) in the model with the return on assets (ROA) ratio as the dependent variable provides a direct empirical way to test for long-run equilibrium. The idea behind this test is that, in an equilibrium, the return on bank assets should not be related to input prices.

The null hypothesis of a long-term equilibrium in the Polish banking sector on a conventional level cannot be rejected on the basis of the Wald test, which means that the condition for using the Panzar and Rosse method was met (the result of the test is shown in Table B.2 in Appendix).

\section{Conclusions}

Similar to its counterparts in other EU10 countries, the Polish banking sector has undergone intense transformation and development in recent years. The modernization of distribution channels and the implementation of new technology have increased the availability of services and the effectiveness of banks' operations. The results of the empirical analysis of the Polish banking sector showed that commercial banks operated under monopolistic competition in the 1997-2007 period. The degree of competition in the Polish banking sector is close to that in euro-area banking sectors, which is reflected in the values of the Panzar and Rosse measures. This assessment refers to both corporate and retail banking.

In the analyzed period, the retail banking market displayed stronger competition than the corporate banking market, but after Poland's EU entry competition in the corporate and retail markets leveled off. However, it should be noted that the value of Panzar and Rosse measures was larger when dependent variables were scaled by asset.

The main impulse for the increased level of competition in the Polish banking sector was the country's entry to the European Union. The same channels - consolidation and financial deregulation - that were observed in the EU at the time of euro adoption influenced banking efficiency and competition in the Polish banking sector at the time of Poland's accession to the EU. This was mainly due to a consolidation process that was strictly connected to the process of privatizing Polish banks - a process based mostly on foreign capital from the euro area.

The estimation results of the $H$-statistic for the three sub-periods have shown a slight increase in this measure. This means that the process of consolidation in the Polish banking system, which has resulted in a slight increase in concentration measures, was not translated into a lower degree of competition in 1997-2007. Consequently, the increased contestability of Poland's banking sector after the country's EU accession may have prevented a decline in competitive pressures. 
It should be noted that the changes taking place in the Polish financial system in recent years as well as changes taking place in other European financial systems have resulted from a number of diverse factors, such as globalization, liberalization, deregulation, progress in the IT sector, progress in European integration, implementation of the FSAP program, and the introduction of the New Basel Capital Accord (Basel II). It is difficult to explicitly state which factor has had the strongest impact on competition among financial institutions and on competition within the Polish banking sector. The global financial crisis is also bound to affect competition in the Polish banking industry, though its implications are difficult to predict at this point. 


\section{Statistical Annex A}

Table A.1

Ownership structure of Poland's banking sector in 1997-2007 (\%)

\begin{tabular}{|c|c|c|c|c|c|c|c|c|c|c|c|}
\hline & 1997 & 1998 & 1999 & 2000 & 2001 & 2002 & 2003 & 2004 & 2005 & 2006 & 2007 \\
\hline 1. Commercial banks & 95.5 & 95.7 & 95.8 & 95.8 & 95.4 & 95.0 & 94.8 & 94.7 & 94.2 & 93.8 & 93.8 \\
\hline $\begin{array}{l}\text { 1.1. Banks controlled by } \\
\text { the state }\end{array}$ & 49.3 & 45.9 & 23.9 & 22.9 & 23.5 & 25.1 & 24.4 & 20.6 & 20.3 & 19.8 & 18.3 \\
\hline $\begin{array}{l}\text { 1.2. Privately-owned banks, } \\
\text { of which }\end{array}$ & 46.2 & 49.8 & 71.8 & 72.9 & 71.9 & 69.9 & 70.4 & 73.5 & 73.1 & 74.3 & 75.5 \\
\hline $\begin{array}{l}\text { 1.2.1. Banks controlled by } \\
\text { Polish owners }\end{array}$ & 30.9 & 33.2 & 24.6 & 3.4 & 3.2 & 2.5 & 2.6 & 6.6 & 4.0 & 4.6 & 4.6 \\
\hline $\begin{array}{l}\text { 1.2.2. Banks controlled } \\
\text { by foreign owners } \\
\text { (including branches } \\
\text { of foreign banks) }\end{array}$ & 15.3 & 16.6 & 47.2 & 69.5 & 68.7 & 67.4 & 67.8 & 66.9 & 69.1 & 69.7 & 70.9 \\
\hline 2. Cooperative banks & 4.5 & 4.3 & 4.2 & 4.2 & 4.6 & 5.0 & 5.2 & 5.3 & 5.8 & 6.2 & 6.2 \\
\hline
\end{tabular}

Source: NBP

Table A.2

The efficiency indicators of commercial banks in Poland 1997-2007 (\%)

\begin{tabular}{|l|r|r|r|r|r|r|r|r|r|r|r|}
\hline \multicolumn{1}{|c|}{ Efficiency ratios } & 1997 & 1998 & 1999 & 2000 & 2001 & 2002 & 2003 & 2004 & 2005 & 2006 & 2007 \\
\hline $\begin{array}{l}\text { Profit before tax over } \\
\text { average assets (ROA) }\end{array}$ & 2.1 & 0.7 & 0.9 & 1.1 & 1.0 & 0.5 & 0.5 & 1.4 & 1.6 & 1.8 & 1.8 \\
\hline $\begin{array}{l}\text { Profit before tax over tier } \\
1 \text { equity (ROE) }\end{array}$ & 37.2 & 9.2 & 12.9 & 14.5 & 12.8 & 5.2 & 5.4 & 17.1 & 20.8 & 23.1 & 22.9 \\
\hline Net interest margin (NIM)1 & 5.4 & 4.7 & 4.0 & 4.0 & 3.5 & 3.3 & 3.1 & 3.1 & 3.2 & 3.3 & 3.1 \\
\hline Non-performing loans (NPL) & 10.7 & 10.9 & 13.2 & 14.9 & 17.8 & 21.1 & 21.2 & 14.7 & 11.5 & 7.6 & 5.5 \\
\hline
\end{tabular}

Note: ${ }^{1}$ Net interest margin $(\mathrm{NIM})=$ net interest income (interest income minus interest expenses) over average assets. ${ }^{2}$ The share of loans which are classified as: substandard, doubtful and loss, in total assets.

Source: NBP

Table A.3

Number of customers who can access their bank accounts via the Internet

\begin{tabular}{|l|c|c|c|}
\hline & 2004 & 2006 & 2007 \\
\hline (in million) & 5.0 & 9.9 & 9.8 \\
\hline
\end{tabular}

Source: Polish Bank Association 
Table A.4

Consolidation in euro-area countries

\begin{tabular}{|l|r|r|r|r|r|c|}
\hline \multicolumn{1}{|c|}{ Country } & $\begin{array}{c}\text { Number } \\
\text { of CIs in 1995 }\end{array}$ & $\begin{array}{c}\text { Number } \\
\text { of CIs } \\
\text { in } 2004\end{array}$ & $\begin{array}{c}\text { Number } \\
\text { of branches } \\
\text { in } 1995\end{array}$ & $\begin{array}{c}\text { Number } \\
\text { of branches } \\
\text { in 2003 }\end{array}$ & $\begin{array}{c}\text { Number } \\
\text { of M\&As } \\
\text { in 1995-2004 }\end{array}$ & $\begin{array}{c}\text { Of which } \\
\text { cross-border } \\
\text { M\&As }(\%)\end{array}$ \\
\hline Germany & 3785 & 2148 & 48180 & 47351 & 170 & 17.8 \\
\hline France & 1469 & 897 & 25581 & 25789 & 157 & 21.3 \\
\hline Austria & 1041 & 796 & 4667 & 4395 & 41 & 29.6 \\
\hline Italy & 970 & 787 & 23493 & 30502 & 275 & 12.2 \\
\hline Netherlands & 648 & 461 & 6802 & 3671 & 23 & 57.7 \\
\hline Spain & 506 & 346 & 36465 & 39762 & 95 & 31.6 \\
\hline Finland & 381 & 363 & 1941 & 1252 & 16 & 25.0 \\
\hline Portugal & 233 & 197 & 3446 & 5440 & 38 & 40.0 \\
\hline Luxemburg & 220 & 165 & 348 & 269 & 10 & 92.9 \\
\hline Belgium & 145 & 104 & 7704 & 4989 & 34 & 30.1 \\
\hline Ireland & 56 & 80 & 1043 & 924 & 8 & 62.5 \\
\hline Greece & 53 & 62 & 2404 & 3300 & 34 & 25.7 \\
\hline Euro area & $\mathbf{9 0 7}$ & $\mathbf{6 4 0 6}$ & $\mathbf{1 6 2 0 7 4}$ & $\mathbf{1 6 7 6 4 4}$ & $\mathbf{9 0 1}$ & $\mathbf{2 3 . 2}$ \\
\hline
\end{tabular}

Source: ECB, Monthly Bulletin, May 2005 


\section{Statistical Annex B}

\section{Panzar and Rosse model}

Panzar and Rosse [1977] and Panzar and Rosse [1987] introduce a series of tests based on the properties of reduced-form revenue equations at the firm level on which the hypothesis of monopoly or oligopoly profit maximization places testable restrictions. The original Panzar and Rosse [1987] model for "monopoly" is shown below [Panzar and Rosse, 1987, pp. 445-446]:

Let $\boldsymbol{y}$ be a vector of decision variables that affect a firm's revenues, so that $R=R(y, z)$, where $z$ denote a vector of variables that are exogenous to the firm and shift the firm's revenue function. The firm's cost function also depends on $\boldsymbol{y}$, so that $C=C(y, w, t)$, where $w$ is a vector of factor prices also taken as given by the firm and $t$ is a vector of exogenous variables that shift the firm's cost curve.

The firm's profit function is given by $\pi=R-C=\pi(y, z, w, t)$.

Let $y^{0}$ be the argument that maximizes this profit function $y^{0}=\max \{R(y, z)-C(y, w, t)\}$. Also, let $y^{1}$ be the output quantity that maximizes $y^{1}=\max \{R(y, z)-C(y, w(1+h), t)\}$ where the scalar $h$ is greater or equal to zero. Also, let $R^{0}=R\left(y^{0}, z\right) \equiv R^{*}(z, w, t)$ and $R^{1}=R\left(y^{1}, z\right) \equiv R^{*}$ $(z,(1+h) w, t)$, where $R^{*}$ is the firm's reduced-form revenue function.

Then, by definition:

$$
R^{1}-C\left(y^{1}, w(1+h), t\right) \geq R^{0}-C\left(y^{0}, w(1+h), t\right)
$$

Using the fact that the cost function is linearly homogeneous in $w$, this can be written as

$$
R^{1}-(1-h) \cdot C\left(y^{1}, w, t\right) \geq R^{0}-(1+h) \cdot C\left(y^{0}, w, t\right)
$$

Similarly, it must also be the case that:

$$
R^{0}-C\left(y^{0}, w, t\right) \geq R^{1}-C\left(y^{1}, w, t\right)
$$

Multiplying both sides of (3) by $1+h$ and adding the result to (2) yields:

$$
-h \cdot\left(R^{1}-R^{0}\right) \geq 0
$$

Dividing both sides of (4) by $-h^{2}$, we obtain:

$$
\frac{R^{1}-R^{0}}{h}=\frac{R \cdot(z, w(1+h), t)-R \cdot(z, w, t)}{h} \leq 0
$$

This is the non-parametric result that indicates that a proportional cost increase will result in a decrease of the firm's revenues. Assuming that the 
reduced-form revenue equation is differentiable, taking the limit of (4) for $h \rightarrow 0$ and dividing by $R^{*}$ yields:

$$
\frac{\partial R^{*}}{\partial w_{i}} \leq 0
$$

and finally:

$$
H \equiv \sum_{k=1}^{m} \frac{\partial R^{*}}{\partial w_{i}} \cdot \frac{w_{k}}{R^{*}} \leq 0
$$

where $w_{i}$ are the components of vector $w$, so that $w_{i}$ denotes the price of the $i_{\text {th }}$ input factor.

Thus we have established that the sum of the factor price elasticities of a monopolist's reduced-form revenue equation $H$ must be non-positive. The test $H$-statistic tries to answer what is the percentage change in the firm's equilibrium revenue resulting from a $1 \%$ increase in all factor prices. An increase in factor prices shifts up all the cost curves, including the marginal cost curve. Consequently, the price charged by the monopolist goes up and the quantity decreases. Since the monopolist operates on the elastic portion of the demand curve, the total revenue decreases. Hence, $H$ is non-positive. 


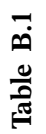

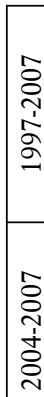

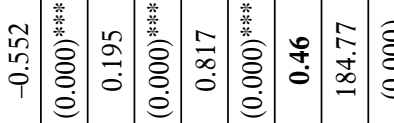

ஃ

官

$\underset{\Xi}{\Xi}$

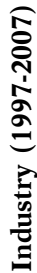

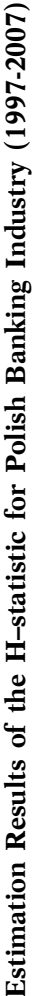

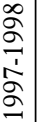

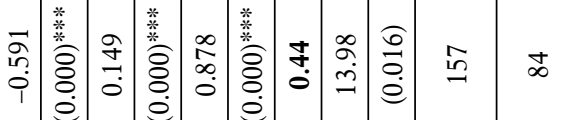

(3)

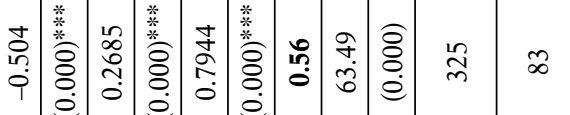

ธิ

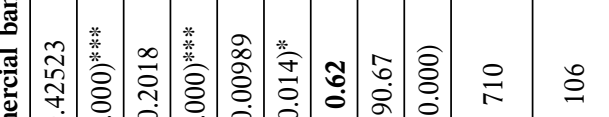

ลั

ठ․․

ธิธ

$+$

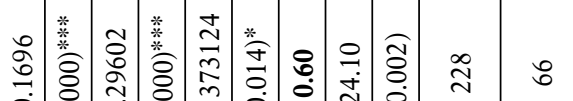

喜

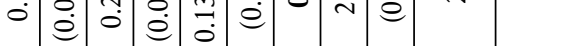

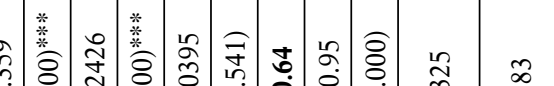

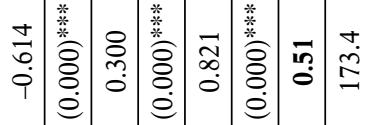

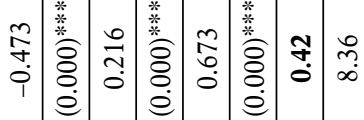

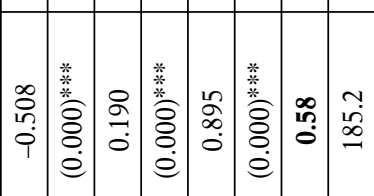

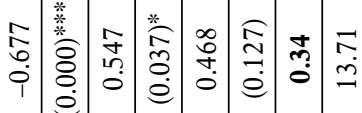

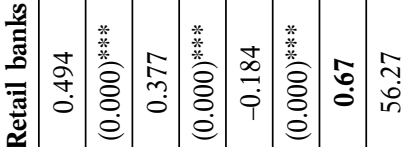

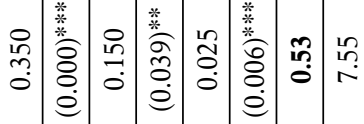

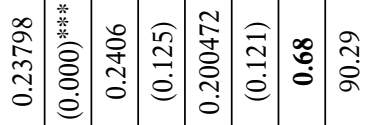

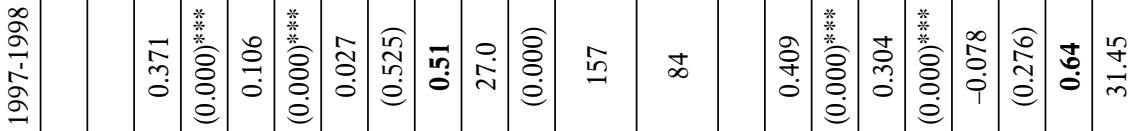

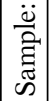

\section{岁}

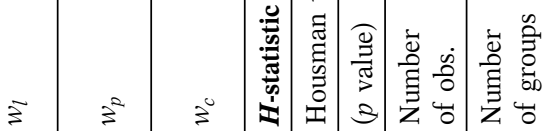

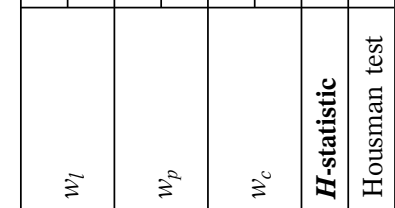




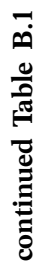

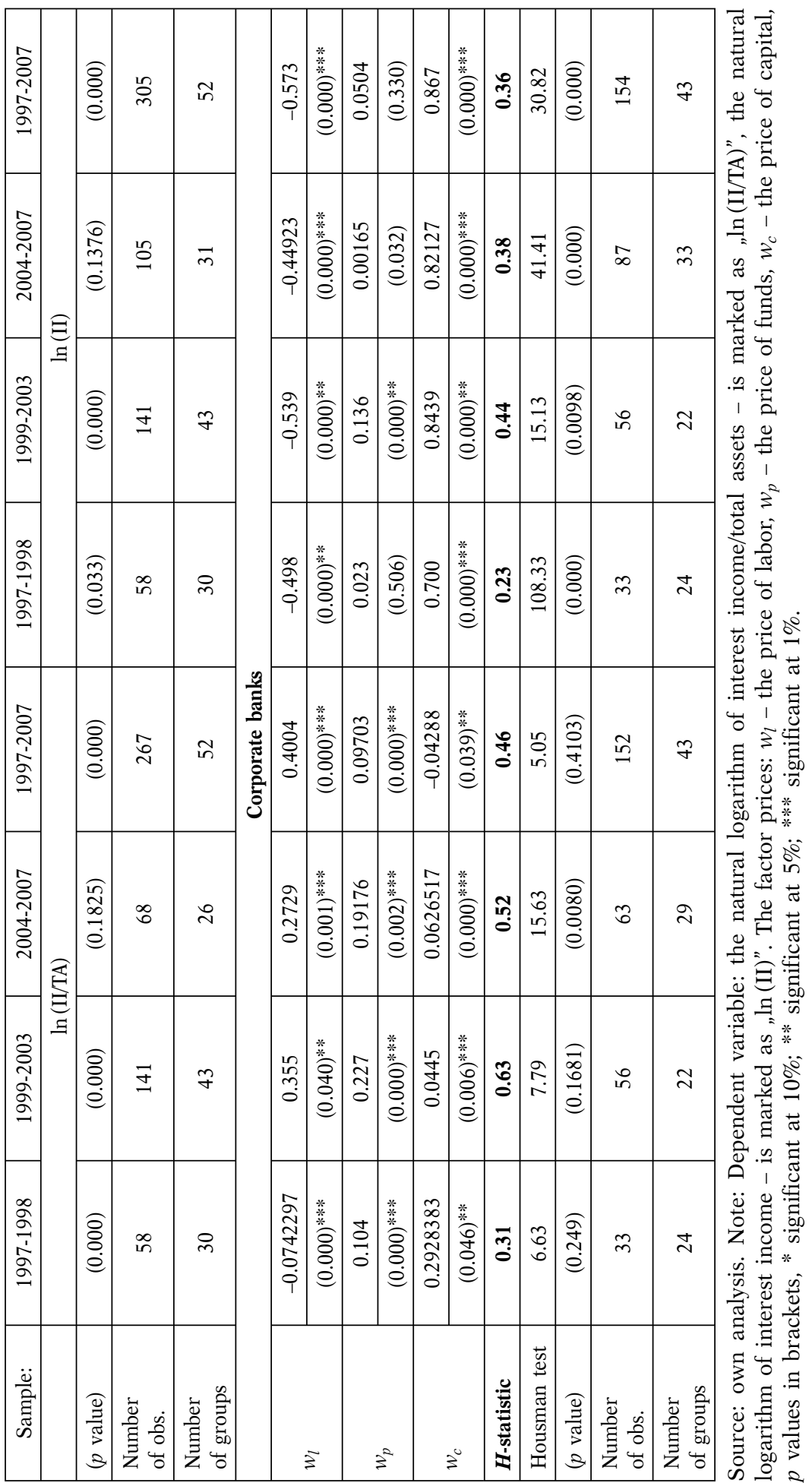


Equilibrium test for the Polish banking industry (1997-2007)

\begin{tabular}{|l|l|l|}
\hline ROA & \multicolumn{1}{|l|}{ Wald test for $H=0$} \\
\hline \multicolumn{3}{|c|}{ Null Hypothesis Summary: } \\
\hline Normalized restriction $(=0)$ & Value & Probab. \\
\hline $\boldsymbol{H}$-statistic & $\mathbf{0 . 0 8 1 1 2 6}$ & 0.2696 \\
\hline
\end{tabular}

Note: In the linear regression in equation (10) ROA was used as a dependent variable. $H<0$ denotes a disequilibrium, while $H=0$ means an equilibrium. The existence of an equilibrium is confirmed for the Polish banking sector (significant at 1 per cent).

Source: own analysis

\section{References}

Baltagi B.H., [2001], Econometric Analysis of Panel Data, second edition, John Wiley \& Sons, Ltd., Britain.

Bikker J.A., [2004], Competition and Efficiency in a Unified European Banking Market, Edward Elgar, Cheltenham, UK, and Northampton, Ma., USA.

Bikker J.A., Haaf W.B., [2002], Competition, concentration and their relationship: an empirical analysis of the banking industry, „Journal of Banking \& Finance”, No. 26, pp. 2191-2214.

Bikker J.A., Bos W.B., [2008], Bank Performance: A theoretical and empirical framework for the analysis of profitability, competition and efficiency, Routledge International Studies in Money and Banking, No. 2.

Bikker J.A., Spierdijk L., Finnie P., [2006], The Impact of Bank Size on Market Power, Working Paper No. 120, DNB.

Bikker J.A., Spierdijk L., Finnie P., [November 2007], The impact of market structure, contestability and institutional environment on banking competition, DNB Working Paper, No. 156.

Bikker J.A., Spierdijk L., Finnie P., [2007a], Misspecification of the Panzar-Rosse Model: Assessing Competition in the Banking Industry, Working Paper No. 114, DNB.

Bikker J.A., Spierdijk L., Finnie P., [2007b], The impact of market structure, contestability and institutional environment on banking competition, Working Paper No. 156, DNB.

Bikker J.A., Spierdijk L., [2008], How Banking Competition Changed over Time, Working Paper No. 167 , DNB.

Boone J., [2000], Competition, Discussion Paper, No. 2636, CEPR, London.

Boucinha M., Ribeiro N., [2009], An assessment of competition in the Portuguese banking system in the 1991-2004 period, Working Papers, Banco de Portugal, 1.

Bresnahan T., [1989], Empirical studies in industries with market power, [in:] Schmelensee R., Willig R. (eds.), Handbook of Industrial Organisation, Vol. II, pp. 1011-1058.

Claessens S., Laeven L., [2004], What Drives Bank Competition? Some International Evidence, „Journal of Money, Credit, and Banking”, Vol. 36, No. 3, pp. 563-584.

Coccorese P., [2004], Banking competition and macroeconomic conditions: a disaggregate analysis, „Journal of International Financial Markets”, Institutions \& Money 14, pp. 203-219.

Corts K.S., [1999], Conduct Parameters and Measurement of Market Power, „Journal of Econometrics", Vol. 88, No. 2, pp. 227-250.

Demsetz H., [1973], Industry Structure, Market Rivalry, and Public Policy, „Journal of Law and Economics", Vol. 16, No. 1, pp. 1-9.

ECB, [2005], Monthly Bulletin, May.

ECB, [2007a], EU Banking Structures. 
ECB, [2007b], Financial Integration in Europe.

ECB, [2007c], Green Paper on Retail Banking.

Freixas X., Rochet J.-CH., [2008], Microeconomics of Banking, The MIT Press, Cambridge, London, England, p. 72-73.

Gelos R.G., Roldos J., [2002], Consolidation and Market Structure in Emerging Market Banking Systems, Working Paper No. 2, IMF, Washington, D.C.

Gutiérrez de Rozas L., [2007], Testing for Competition in the Spanish Banking Industry: The Panzar-Rosse Approach Revisited, Banco de España, Documentos de Trabajo, No. 0726.

Hempell H.S., [2002], Testing for Competition Among German Banks, Discussion Paper No. 4, Economic Research Center of Deutsche Bundesbank.

Iwata G., [1974], Measurement of conjectural variations in oligopoly, „Econometrica” 42, pp. 947-966.

Koutsomanoli-Fillipaki N., Staikouras C.H., [2006], Competition and Concentration in the New European Banking Landscape, „European Financial Management”, Vol. 12, No. 3, 443-482.

Lau L., [1982], On identifying the degree of competitiveness from industry price and output data, „Economics Letters” 10, 93-99.

Leuvensteijn M., Bikker J.A., Rixtel A., Sørensen C.K., [June 2007], A new approach to measuring competition in the loan markets of the euro area, EBC, Working Paper Series, No. 768.

Łyszkiewicz W., [2002], Industrial Organization, Organizacja Rynku i Konkurencja, Dom Wydawniczy Elipsa, Warszawa, p. 266.

Molyneux P., Lloyd-Williams D.M., Thornton J., [1994], Competitive conditions in European banking, „Journal of Banking and Finance”, Vol. 18, pp. 445-459.

Nathan A., Neave E.H., [1989], Competition and contestability in Canada's financial system: empirical results, „Canadian Journal of Economics”, Vol. 22, No. 3, pp. 576-594.

National Bank of Poland, [2007), Financial System Development Report, Warsaw.

Rosse J.N., Panzar J.C., [1977], Chamberlin vs Robinson: An empirical study for monopoly rents, Bell Laboratories Economic Discussion Paper.

Panzar J.C., Rosse J.N., [1987], Testing for “monopoly” equilibrium, „Journal of Industrial Economics", No. 35, pp. 443-456.

Pawłowska M., [2005], Competition, Concentration, Efficiency and their Relationship in the Polish Banking Sector, Materiały i Studia, No. 32, NBP, Warsaw.

Pawłowska M., Kozak S., [2008], Efficiency and Competition in the Polish Banking Sector: Has Euro Adoption Changed Them?, Bank and Credit, No. 12, NBP, Warsaw.

Polish Financial Supervision Authority, [2008], Summary Evaluation of the Financial Performance of Polish Banks in 2007.

Sealey C.W., Lindley J.T., [1977], Inputs, Outputs and a Theory of Production and Cost at Depository Financial Institutions, „Journal of Finance”, Vol. 32, 1251-1266.

Shaffer S., [1982], Competition, Conduct and Demand Elasticity, „Economic Letters”, Vol. 10, pp. 167-171.

Utrero-González N., Callado-Munoz F.J., [2007], Can Monetary Union Enhance Banking Competition?: A Multicase Study, „Journal of Economic Integration”, Vol. 22, No. 1, pp. 128-155.

Yildrim H.S., Philippatoas G.C., [2007], Competition and Contestability in Central and Eastern European Banking, Managerial Finance 33, 195-209. 


\section{COMPETITION IN THE POLISH BANKING SECTOR}

\section{Su m m a ry}

The paper aims to assess changes in the level of competition in Poland's banking sector in 1997-2007. Competition between banks is one of the most important factors behind the stability of the financial sector through its influence on the profitability of banks, access to external funding, and the country's economic development as a whole. In this paper, the Panzar and Rosse model was applied to assess the level of competition in the banking sector.

The results of the analysis of the Polish banking sector show that between 1997 and 2007 commercial banks operated under monopolistic competition. The degree of competition in the Polish banking sector is close to that in euro-area banking sectors (which is reflected by the values of the Panzar and Rosse measures). This applies to both corporate and retail banking.

The main driving factor behind competition in the Polish banking sector was the country's entry into the European Union. The same channels, i.e. consolidation and financial deregulation, that were observed in the EU at the time of adopting the euro influenced competition between banks in the Polish banking sector at the time of EU entry. This was mainly due to foreign capital from the euro area.

Keywords: competition; concentration; market structure; Panzar-Rosse model 